\title{
ANALISIS PENGARUH DAERAH PEMASOK TERHADAP HARGA CABAI MERAH DI DKI JAKARTA MENGGUNAKAN VECTOR ERROR CORRECTION MODEL (VECM) ${ }^{*}$
}

\author{
Erwandi ${ }^{1}$, Farit Mochamad Afendi ${ }^{2 \ddagger}$, and Budi Waryanto ${ }^{3}$ \\ 1Badan Pusat Statistik Kabupaten Lampung Tengah, Indonesia, erwan@bps.go.id \\ 2Department of Statistics, IPB University, Indonesia, fmafendi@gmail.com \\ ${ }^{3}$ Ministry of Agriculture Republic Indonesia, Indonesia, budi_w@pertanian.go.id \\ ‡corresponding author
}

Indonesian Journal of Statistics and Its Applications (eISSN:2599-0802)

Vol 3 No 3 (2019), 216 - 235

Copyright (C) 2019 Erwandi, Farit Mochamad Afendi, and Budi Waryanto. This is an open-access article distributed under the Creative Commons Attribution License, which permits unrestricted use, distribution, and reproduction in any medium, provided the original work is properly cited.

\begin{abstract}
This study aims to analyze the effect of red chili price and production in the supplier area on its prices in DKI Jakarta using the Vector Error Correction Model (VECM). The data used in this study are red chili price and average expenditure per month per capita in DKI Jakarta and red chili price and production in East Java, West Java, and Banten in the period January 2012 to July 2018. The model obtained was VECM (1) the price of red chili in DKI Jakarta. It showed that there was a long-term relationship (cointegration) on the first difference. The results the Forecast Error Variance Decomposition (FEVD) analysis showed that the contributions of the red chili price in DKI Jakarta and West Java, average monthly expense for red chili in DKI Jakarta, red chili production (West Java and Banten) are significant in explaining the behaviour of the red chili price change in DKI Jakarta. The results of the Impulse Response Function (IRF) analysis showed that the shock of the price of chili in DKI Jakarta and West Java in the previous month will increase the price of red chili in DKI Jakarta in the following month. Conversely, the shock of the average monthly expenditure of red chili in DKI Jakarta and red chili production (West Java and Banten) from the previous month will reduce the price of red chili in DKI Jakarta in the following month.
\end{abstract}

Keywords: forecast error variance decomposition, impulse response function, red chili price, vector error correction model.

"Received Apr 2019; Accepted Aug 2019; Published online on Oct 2019 


\section{Pendahuluan}

Cabai merah merupakan komoditas strategis tetapi harganya rentan mengalami fluktuasi. Oleh karena itu, peran pemerintah sangat dibutuhkan dalam permasalahan ini. Beberapa penelitian terkait fluktuasi harga cabai merah telah dilakukan oleh Syah et al. (2015), Nauly (2016), Sukmawati et al. (2016), dan Wulandari et al. (2017). Fluktuasi harga cabai merah mempunyai peran dalam pembentukan inflasi/deflasi di DKI Jakarta. Cabai merah termasuk salah satu komponen dari penghitungan inflasi. Pada periode 2014 sampai 2018, rataan sumbangan inflasi/deflasi komoditas cabai merah di DKI Jakarta berkisar -0.001 persen (BPS, 2019). Demi memenuhi pasokan cabai merah setiap daerah di Indonesia, hasil Survei Pola Distribusi 2015 melaporkan bahwa hampir setiap daerah melakukan transaksi perdagangan dengan daerah lainnya (BPS, 2015). Transaksi perdagangan tersebut termasuk dalam bentuk pembelian dan penjualan cabai merah. Farid \& Subekti (2012) melaporkan bahwa DKI Jakarta merupakan tujuan utama pemasaran cabai merah di Indonesia. Hal ini dikarenakan jumlah konsumsi yang tinggi meskipun DKI Jakarta bukan merupakan daerah produsen cabai merah.

Produksi cabai merah yang rendah di suatu daerah dapat memengaruhi penawaran atau pasokan (supply). Hal ini dikarenakan jumlah produksi cabai merah ditentukan oleh luas panen dan produktivitas lahan. Pusdatin - Kementan (2016) mencatat bahwa produksi cabai merah di Indonesia sampai tahun 2015 mencapai 1.915,12 juta ton. Sepanjang periode 1989 sampai 2015, rataan pertumbuhan cabai merah di Indonesia mencapai $9,76 \%$ pertahun.

Pergerakan harga cabai merah ditentukan oleh dinamika distribusi dan produksi (Prastowo et al., 2008). Jika terjadi gangguan distribusi atau produksi tesebut dapat mengakibatkan gejolak pada mekanisme pasokan dan permintaan (demand). Sari (2013) menyatakan bahwa jika jumlah pasokan pangan lebih sedikit dibandingkan jumlah permintaan dapat menyebabkan kenaikan harga, sehingga dapat menjadi pemicu meningkatnya inflasi. Rozfaulina (2000) menyatakan bahwa cabai merah memiliki karaktekteristik permintaan yang inelastis dalam jangka pendek. Dengan kata lain, secara teoritis terdapat hubungan antara penentuan harga cabai merah dengan pasokan dan permintaan.

Pemerintah telah membuat aturan baku tentang penentuan harga cabai merah melalui Permendag Nomor 63/M-DAG/PER/09/2016 tentang harga acuan pembelian dan penjualan. Harga acuan pembelian cabai merah di tingkat petani adalah Rp 15000/kg. Sementara itu, harga acuan penjualan di tingkat konsumen adalah Rp 28500/kg (Kemendag, 2016). Namun, pada kenyataanya penentuan harga cabai masih dikendalikan oleh pasar.

Pemodelan harga cabai merah di DKI Jakarta dibutuhkan sebagai langkah antisipasi apabila harga cabai merah tidak terkendali. Selain itu, juga dapat diketahui faktor-faktor yang memengaruhi perubahan harga tersebut pada periode yang akan datang. Informasi ini penting digunakan sebagai acuan bagi petani, pedagang, konsumen dan pemangku kebijakan dalam menjaga stabilitas harga dan pasokan cabai merah di pasaran. 
Sering kali data komoditas pertanian berupa data dalam kondisi yang tidak stasioner sehingga apabila digunakan dapat menghasilkan regresi palsu (spurious regression). Pergerakan data pada regresi palsu terjadi secara kebetulan dan tidak memiliki dasar teori dan logika (Juanda \& Junaidi, 2012). Penelitian ini menitikberatkan pada penggunaan VECM yang merupakan bentuk model Vector Autoregressive (VAR) yang terestriksi. Restriksi ini diberikan akibat dari permasalahan data yang tidak stasioner, tetapi mempunyai hubungan jangka panjang (kointegrasi) (Juanda \& Junaidi, 2012). Uji kointegrasi ini sebagai langkah awal untuk mengantisipasi adanya regresi palsu sehingga data yang akan dianalisis nanti tidak akan memberikan informasi yang menyesatkan. Adapun tujuan penelitian ini yaitu menganalisis pengaruh harga dan produksi cabai merah daerah pemasok terhadap harga cabai merah di DKI Jakarta menggunakan model VECM.

\section{Metodologi}

\subsection{Bahan dan Data}

Data yang digunakan dalam penelitian ini (Tabel 1) adalah data bulanan yang berasal dari Kementerian Perdagangan (Kemendag), Badan Pusat Statistik (BPS) dan Kementerian Pertanian (Kementan). Periode penelitian ini adalah Januari 2012 sampai Juli 2018. Data tersebut dibagi menjadi dua, yaitu data latih (Januari 2012 - Maret 2018) dan data uji (April 2018-Juli 2018). Data latih digunakan untuk pembentukan model sedangkan data uji untuk evaluasi model. Sumber informasi daerah pemasok cabai merah DKI Jakarta berdasarkan publikasi Survei Pola Distribusi 2015 BPS. Pemilihan peubah-peubah penelitian memperhatikan kelengkapan data selama periode penelitian.

Tabel 1: Peubah pada Penelitian DKI Jakarta.

\begin{tabular}{llll}
\hline Peubah & \multicolumn{1}{c}{ Keterangan } & \multicolumn{1}{c}{ Satuan } & Sumber data \\
\hline $\mathrm{Y}$ & Harga cabai merah DKI Jakarta & $\mathrm{Rp} / \mathrm{kg}$ & Kemendag \\
$\mathrm{X}_{1}$ & Harga cabai merah Jawa Timur & $\mathrm{Rp} / \mathrm{kg}$ & Kemendag \\
$\mathrm{X}_{2}$ & Harga cabai merah Jawa Barat & $\mathrm{Rp} / \mathrm{kg}$ & Kemendag \\
$\mathrm{X}_{3}$ & Harga cabai merah Banten & $\mathrm{Rp} / \mathrm{kg}$ & Kemendag \\
$\mathrm{X}_{4}$ & Pengeluaran rata-rata perkapita & $\mathrm{Rp} / \mathrm{kapita}$ & $\mathrm{BPS}$ \\
& sebulan cabai merah DKI Jakarta & /bulan & \\
$\mathrm{X}_{5}$ & Produksi cabai merah Jawa Timur & Ton & Kementan \\
$\mathrm{X}_{6}$ & Produksi cabai merah Jawa Barat & Ton & Kementan \\
$\mathrm{X}_{7}$ & Produksi cabai merah Banten & Ton & Kementan \\
\hline
\end{tabular}




\subsection{Metode Penelitian}

\section{a. Vector Autoregressive (VAR)}

Sims et al. (1990) memperkenalkan model Vector Autoregressive (VAR) ke dalam ilmu ekonomi dan memperluas cakupan penerapannya pada model sistem dinamis. Model VAR merupakan bentuk pengembangan dari model Autoregressive (AR), dimana terdapat sistem persamaan yang menunjukkan bahwa setiap peubah sebagai fungsi linier dari konstanta. Nilai setiap peubah dalam sebuah sistem persamaan tidak hanya bergantung pada lag (lampau) sendiri tetapi pada nilai lag peubah lain.

Model VAR dengan ordo ke- $p$ dan $n$ buah peubah tak bebas pada periode ke-t dapat dituliskan sebagai berikut (Enders, 2004):

dimana

$$
\mathbf{y}_{\mathbf{t}}=\mathbf{A}_{\mathbf{0}}+\sum_{\mathrm{i}=\mathbf{1}}^{\mathrm{p}} \mathbf{A}_{\mathrm{i}} \mathbf{y}_{\mathbf{t}-\mathbf{i}}+\boldsymbol{\varepsilon}_{\mathrm{t}}
$$

$\mathbf{y}_{\mathbf{t}}=$ vektor peubah tak bebas ke-t berukuran $\mathrm{n} \times 1$

$\mathbf{A}_{\mathbf{0}}=$ vektor intersep berukuran $\mathrm{n} \times 1$

$\mathbf{A}_{\mathbf{i}}=$ matriks parameter berukuran $\mathrm{n} \times \mathrm{n}$ untuk setiap $\mathrm{i}=1,2, \ldots, \mathrm{p}$

$\varepsilon_{\mathrm{t}}=$ vektor sisaan berukuran $\mathrm{n} \times 1$

Asumsi yang harus dipenuhi dalam model VAR, yaitu:

1. Semua peubah tak bebas bersifat stasioner dalam rataan dan ragam pada ordo (tingkat) yang sama.

2. Semua sisaan bersifat white noise. Artinya semua sisaan memiliki rataan nol, ragam konstan, tidak ada korelasi diri (Autocorrelation) dan bersifat acak.

Model VAR tidak dibangun dengan dasar teori ekonomi yang rumit namun lebih menekankan pada kestasioneran data dalam membangun model regresinya. Jika data yang digunakan stasioner pada ordo lebih dari 0 dan terjadi hubungan kointegrasi maka bentuk model VAR yang digunakan adalah Vector Error Correction Model (VECM).

\section{b. Vector Error Correction Model (VECM)}

VECM merupakan perluasan dari bentuk Error Corection Model (ECM) ketika menangani dua atau lebih peubah dalam bentuk vektor. ECM digunakan untuk mengoreksi persamaan regresi di antara peubah-peubah parsial yang tidak stasioner agar kembali ke nilai keseimbangan jangka panjang, dengan syarat peubah-peubah penyusunnya memiliki hubungan kointegrasi. Secara umum model VECM(p) dengan kointegrasi rank $\Pi \leq \mathrm{k}$, dimana $\mathrm{k}$ adalah rank banyaknya vektor kointegrasi yang saling bebas sehingga persamaannya dapat dituliskan sebagai berikut (Enders, 2004):

$$
\Delta y_{t}=A_{0}+\Pi y_{t-1}+\sum_{i=1}^{p-1} \Gamma_{i} \Delta y_{t-i}+\varepsilon_{t}
$$


di mana

$\Delta=$ operator pendiferensiasian, dimana $\Delta \mathbf{y}_{\mathbf{t}}=\mathbf{y}_{\mathbf{t}}-\mathbf{y}_{\mathbf{t}-\mathbf{1}}$

$\mathbf{A}_{\mathbf{0}}=$ vektor intersep berukuran $\mathrm{n} \times 1$

$\Pi=$ matriks koefisien kointegrasi $\left(\boldsymbol{\Pi}=\boldsymbol{\alpha} \boldsymbol{\beta}^{\prime}\right)$ berukuran $\mathrm{n} \times \mathrm{k}$ dimana $\boldsymbol{\alpha}$ adalah

vektor penyesuaian jangka panjang, $\boldsymbol{\beta}$ adalah vektor kointegrasi

(parameter jangka panjang).

$\mathbf{y}_{\mathbf{t}-\mathbf{1}}=$ vektor peubah bebas pada lag ke-1 berukuran $\mathrm{n} \times 1$

$\boldsymbol{\Gamma}_{\mathbf{i}}=$ koefisien matriks peubah bebas ke-i berukuran $\mathrm{n} \times \mathrm{n}$ untuk setiap $\mathrm{i}=$ $1,2, \ldots, \mathrm{p}-1$

$\boldsymbol{\varepsilon}_{\mathbf{t}} \quad=$ vektor sisaan berukuran $\mathrm{n} \times 1$

Analisis hubungan jangka panjang pada Model VECM didapatkan melalui persamaan kointegrasinya sedangkan hubungan jangka pendek didapatkan melalui uji Wald Statistics untuk menentukan signifikansi pengaruh peubah bebasnya.

\section{c. Impulse Response Function (IRF)}

IRF merupakan komponen analisis model VAR yang digunakan untuk melihat dampak perubahan dari satu peubah terhadap peubah lainnya. IRF akan menelusuri pengaruh goncangan (shock) satu peubah dalam sistem persamaan terhadap nilai seluruh peubah pada saat ini dan beberapa periode mendatang (Juanda \& Junaidi, 2012). Shock yang diberikan sebesar satu simpangan baku dari peubah tersebut.

Jika vektor yt merupakan vektor yang stasioner dalam koragam maka dapat dinyatakan dalam bentuk Vector Moving Average (VMA) sebagai berikut (Enders, 2004):

$$
\mathbf{y}_{\mathbf{t}}=\boldsymbol{\mu}+\sum_{\mathrm{i}=\mathbf{0}}^{\infty} \boldsymbol{\Phi}_{\mathrm{i}} \boldsymbol{\varepsilon}_{\mathrm{t}-\mathrm{i}}
$$

dengan

$\boldsymbol{\mu}=$ rataan dari peubah tak bebas ke-t berukuran $\mathrm{n} \times 1$

$\boldsymbol{\varepsilon}_{\mathbf{t}-\mathbf{i}}=$ vektor sisaan berukuran $\mathrm{n} \times 1$ untuk setiap $\mathrm{i}=1,2, \ldots, \infty$

$\boldsymbol{\Phi}_{\mathbf{i}}=$ matriks impulse response function berukuran $\mathrm{n} \times \mathrm{n}$

\section{d. Forecast Error Variance Decomposition (FEVD)}

FEVD merupakan komponen analisis model VAR yang digunakan untuk menggambarkan kekuatan atau kelemahan setiap peubah dalam memengaruhi peubah lainnya. FEVD akan memisahkan keragaman sejumlah peubah yang diduga menjadi komponen shock. Dekomposisi ragam memberikan informasi mengenai proporsi dari pergerakan pengaruh shock pada sebuah peubah terhadap shock peubah lainnya pada periode saat ini dan periode yang akan datang (Ajija et al., 2011). 
Misalkan diberikan $\mathrm{n}=2$ peubah tak bebas yaitu peubah $\mathrm{yt}_{\mathrm{t}}$ dan peubah $\mathrm{z}_{\mathrm{t}}$ sehingga ragam peramalan sisaan $n$ periode ke depan untuk $y_{t}$ dapat dihitung sebagai berikut (Enders, 2004):

$$
\begin{gathered}
\sigma_{\mathrm{y}}^{2}(\mathrm{n})=\sigma_{\mathrm{y}}^{2}\left[\phi_{11}^{2}(0)+\phi_{11}^{2}(1)+\ldots+\phi_{11}^{2}(\mathrm{n}-1)\right]+\sigma_{\mathrm{z}}^{2}\left[\phi_{12}^{2}(0)+\right. \\
\left.\phi_{12}^{2}(1)+\ldots+\phi_{12}^{2}(\mathrm{n}-1)\right]
\end{gathered}
$$

Kemudian, dekomposisi ragam sisaan $\mathrm{n}$ periode ke depan terhadap masingmasing shock dapat dilakukan. Proporsi $\sigma_{\mathrm{y}}^{2}(\mathrm{n})$ terhadap masing-masing shock $\varepsilon_{\mathrm{y}_{\mathrm{t}}}$ dan $\varepsilon_{\mathrm{z}_{\mathrm{t}}}$ dapat dihitung sebagai berikut:

$$
\frac{\sigma_{y}^{2}\left[\phi_{11}^{2}(0)+\phi_{11}^{2}(1)+\ldots+\phi_{11}^{2}(n-1)\right]}{\sigma_{y}^{2}(n)}
$$

dan

$$
\frac{\sigma_{\mathrm{z}}^{2}\left[\phi_{12}^{2}(0)+\phi_{12}^{2}(1)+\ldots+\phi_{12}^{2}(\mathrm{n}-1)\right]}{\sigma_{\mathrm{y}}^{2}(\mathrm{n})}
$$

Adapun Langkah-langkah analisis data yang dilakukan dalam penelitian ini adalah sebagai berikut:

1. Menampilkan gambaran umum data dengan melakukan eksplorasi data dan memeriksa kestasioneran data setiap peubah secara visual untuk melihat tren data atau grafik.

2. Melakukan pengujian kestasioneran data secara formal dengan uji kestasioneran data dalam rataan dengan uji akar unit Augmented Dickey Fuller (ADF) dan uji kestasioneran data dalam ragam menggunakan uji Barlett.

a. Uji akar unit Augmented Dickey Fuller (ADF).

Uji ADF merupakan uji kestasioneran dalam rataan untuk data peubah deret waktu yang paling umum digunakan. Uji ADF sebagai bentuk perluasan dari uji Dickey fuller dimana tidak semua data deret waktu dapat terwakilkan dengan baik dengan model AR(1). Misalkan data deret waktu $y_{t}$ mengikuti model AR(p) dimana lag ke $p \geq 1$, setelah menambahkan nilai lag $p$ pada peubah tak bebas $y_{t}$ dan dengan pendiferensiasian maka persamaanya dapat dituliskan sebagai berikut:

$$
\Delta y_{t}=\alpha_{0}+\gamma y_{t-1}+\sum_{i=2}^{p} \beta_{i} \Delta y_{t-i+1}+\varepsilon_{t}
$$

dimana

$\alpha_{0}=$ intersep

$\gamma=$ koefisien autoregressive

$\beta_{i}=$ koefisien autoregressive pembedaan, dimana $i=2,3, \ldots, p$

Hipotesis yang diuji

$\mathrm{H}_{0}$ : intersep $\gamma=0$ (terdapat akar unit, artinya data deret waktu tidak stasioner)

$\mathrm{H}_{1}: \gamma<0$ (tidak terdapat akar unit, artinya data deret waktu stasioner) 
Statistik uji

dimana

$$
t_{\text {hitung }}=\frac{\hat{\gamma}}{\sigma_{\widehat{\gamma}}}
$$

$\hat{\gamma}=$ nilai dugaan $\gamma$

$\sigma_{\widehat{\gamma}}=$ simpangan baku dari $\hat{\gamma}$.

Kriteria pengujian, tolak $\mathrm{H}_{0}$ jika nilai $\mathrm{p}<$ taraf nyata $(\alpha)=5 \%$, artinya tidak terdapat akar unit atau data deret waktu stasioner pada taraf nyata $(\alpha)$ sebesar 5\% (Dickey \& Fuller, 1979). Jika data tidak stasioner dalam rataan dilakukan pembedaan orde ke-1.

b. Uji Barlett.

Uji Barlett adalah uji kestasioneran dalam ragam untuk data peubah deret waktu yang paling umum digunakan. Uji Barlett yang memiliki kuasa uji terbaik dalam pengujian kehomogenan ragam apabila digunakan pada data menyebar simetris (normal atau seragam) (Hatidja, 2000).

Hipotesis yang akan diuji

$\mathrm{H}_{0}: \sigma_{1}^{2}=\sigma_{2}^{2}=\cdots=\sigma_{\mathrm{t}}^{2}$ (ragam homogen, artinya data deret waktu

stasioner)

$\mathrm{H}_{1}$ : minimal ada sepasang $\sigma_{\mathrm{i}}^{2} \neq \sigma_{\mathrm{j}}^{2}$ untuk $\mathrm{i} \neq \mathrm{j}$ (ragam tidak homogen, artinya data deret waktu tidak stasioner).

Statistik uji

$$
\begin{gathered}
\left.\chi_{\text {hitung }}^{2}=\ln 10\left\{\left(\sum_{\mathrm{i}}\left(\mathrm{n}_{\mathrm{i}}-1\right)\right) \log \left(\mathrm{s}^{2}\right)-\sum_{\mathrm{i}}\left(\mathrm{n}_{\mathrm{i}}-1\right)\right) \log \left(\mathrm{s}_{\mathrm{i}}^{2}\right)\right\} \\
\mathrm{s}^{2}=\frac{\sum\left(\mathrm{n}_{\mathrm{i}}-1\right) \mathrm{s}_{\mathrm{i}}^{2}}{\mathrm{~N}-\mathrm{a}}
\end{gathered}
$$

dimana

$\mathrm{n}_{\mathrm{i}}=$ banyaknya ulangan pada kelompok ke-i

$\mathrm{s}^{2}=$ ragam kumulatif contoh

$s_{i}^{2}=$ ragam contoh ke-i

$\mathrm{N}$ = banyaknya amatan

a = banyaknya perlakuan.

Faktor koreksi:

$$
\begin{gathered}
\mathrm{C}=1+\frac{1}{3(\mathrm{a}-1)}\left(\sum_{\mathrm{i}} \frac{1}{\left(\mathrm{n}_{\mathrm{i}}-1\right)}-\frac{1}{\sum_{\mathrm{i}}\left(\mathrm{n}_{\mathrm{i}}-1\right)}\right) \\
\chi_{\text {terkoresi }}^{2}=\frac{\chi_{\text {hitung }}^{2}}{\mathrm{C}}
\end{gathered}
$$

Kriteria pengujian, tolak $\mathrm{H}_{0}$ jika nilai $\mathrm{p}<$ taraf nyata $(\alpha)=5 \%$, artinya minimal ada sepasang ragam yang tidak sama (ragam tidak homogen) pada taraf nyata (a) sebesar $5 \%$. Jika data tidak stasioner dalam ragam dilakukan transformasi logaritma natural.

3. Melakukan pemilihan kriteria panjang lag (p) optimal dengan menentukan nilai (p) yang diperoleh dari nilai kriteria yang minimum. Lag (p) optimal digunakan untuk melihat seberapa lama lag yang masih berpengaruh nyata dari satu peubah deret 
data terhadap peubah deret data lainnya. Adapun pelbagai kriteria untuk mengetahui panjang lag optimal adalah sebagai berikut (Montgomery et al., 2008):

a. Aikaike's information criterion $(\mathrm{AIC})=\ln \left(\frac{\sum_{\mathrm{t}=1}^{\mathrm{T}} \mathrm{e}_{\mathrm{t}}}{\mathrm{T}}\right)+\frac{2 \mathrm{~m}}{\mathrm{~T}}$

b. Schwarz information criterion $(\mathrm{SIC})=\ln \left(\frac{\sum_{\mathrm{t}=1}^{\mathrm{T}} \mathrm{e}_{\mathrm{t}}}{\mathrm{T}}\right)+\frac{\operatorname{mln}(\mathrm{T})}{\mathrm{T}}$

c. Hannan-Quinn criterion $(\mathrm{HQC})=\ln \left(\frac{\sum_{\mathrm{t}=1}^{\mathrm{T}} \mathrm{e}_{\mathrm{t}}}{\mathrm{T}}\right)+\frac{2 \mathrm{~m} \ln (\ln \mathrm{T})}{\mathrm{T}}$

dimana

$\mathrm{T}$ = banyaknya amatan

$e_{t}=$ sisaan model $\operatorname{VAR}(p)$

$\mathrm{m}=$ banyaknya peubah tak bebas.

Selanjutnya, menentukan kriteria Final Prediction Error Corection (FPE) yang merupakan penjumlahan dari AIC, SIC dan HQC yang minimum.

4. Melakukan pengujian stabilitas model VAR dengan menghitung akar-akar fungsi polinomial (roots of characteristic polinomial). Stabilitas model VAR ditunjukkan dari nilai kebalikan dari karakteristik polinomial model VAR(p). Persamaan model $\operatorname{Var}(\mathrm{p})$ dikatakan stabil dapat dituliskan sebagai berikut:

$$
\operatorname{det}\left(\mathbf{I}_{\mathbf{k} \mathbf{p}}-\sum_{\mathbf{i}=\mathbf{1}}^{\mathbf{p}} \mathbf{A}_{\mathbf{i}} \mathbf{z}\right)=\operatorname{det}\left(\mathbf{I}_{\mathbf{k}}-\mathbf{A}_{\mathbf{1}} \mathbf{z}-\mathbf{A}_{\mathbf{2}} \mathbf{z}^{2}-\cdots-\mathbf{A}_{\mathbf{p}} \mathbf{z}^{\mathbf{p}}\right) \neq 0
$$

dimana

$\mathbf{I}_{\mathbf{k}}=$ matriks identitas peubah berukuran $\mathrm{n} \times \mathrm{n}$

$\mathrm{z}=$ operator polinomial pengganti peubah.

Jika $|\mathrm{z} \leq 1|$ artinya semua akar dari fungsional tersebut berada dalam unit circle atau model VAR sudah dianggap stabil (Gujarati, 2003). Ini artinya komponen analisis IRF dan komponen analisis FEVD sudah sahih untuk digunakan.

5. Melakukan pengujian kausalitas granger (Granger Causality Test) untuk menganalisis hubungan kausalitas (sebab akibat) antar peubah dalam model VAR. Misalkan peubah bebas $(\mathrm{X})$ merupakan peubah tak bebas dari $(\mathrm{Y})$ jika nilainilai masa lalu dari peubah $\mathrm{X}$ dapat menjelaskan peubah $\mathrm{Y}$.

Hipotesis yang akan diuji,

$\mathrm{H}_{0}$ : Peubah $X$ bukan penyebab Granger Peubah $\mathrm{Y}$

$\mathrm{H}_{1}$ : Peubah X penyebab Granger Peubah X.

Statistik uji (Juanda \& Junaidi, 2012).

dimana

$$
\mathrm{F}_{\text {hitung }}=(\mathrm{N}-\mathrm{k}) \frac{\left(\mathrm{JKS}_{\mathrm{R}}-\mathrm{JKS}_{\mathrm{UR}}\right)}{\mathrm{m}\left(\mathrm{JKS}_{\mathrm{UR}}\right)}
$$

$\mathrm{JKS}_{\mathrm{R}}=$ jumlah kuadrat sisaan persamaan terestriksi

JKSUR $=$ jumlah kuadrat sisaan persamaan tidak terestriksi

$\mathrm{N} \quad$ = banyaknya amatan

$\mathrm{k} \quad=$ banyaknya parameter pendugaan pada persamaan tak terestriksi

$\mathrm{m}=$ jumlah lag.

Kriteria pengujian, tolak $\mathrm{H}_{0}$ jika nilai $\mathrm{p}<$ taraf nyata $(\alpha)=5 \%$, artinya peubah $\mathrm{X}$ penyebab Granger (memiliki keterkaitan) dengan peubah $Y$ pada taraf nyata $(\alpha)$ 
sebesar $5 \%$. Jika hipotesis nol pada pengujian kedua baris antar peubah yang sama menunjukkan pengaruh nyata maka terdapat hubungan kausalitas dua arah.

6. Melakukan pengujian kointegrasi dengan uji kointegrasi Johansen (Johansen's Cointegration Test) untuk mengukur hubungan jangka panjang (long term equilibrium) antar peubah-peubah yang tidak stasioner. Uji kointegrasi dilakukan jika terdapat paling sedikit satu hubungan kausalitas Granger. Misalkan uji kointegrasi menggunakan metode Johansen $\operatorname{VAR}(p)$ dengan lag $(p)$ optimum sehingga persamaanya dapat dituliskan sebagai berikut: (Johansen, 1991).

$$
\Delta y_{t}=\Pi y_{t-1}+\sum_{i-1}^{p-1} \Gamma_{i} \Delta y_{t-i}+\varepsilon_{t}
$$

dimana $\boldsymbol{\Pi}=\sum_{\mathbf{i}=\mathbf{1}}^{\mathbf{p}} \mathbf{A}_{\mathbf{i}}-\mathbf{I}, \boldsymbol{\Gamma}_{\mathbf{i}}=-\sum_{\mathbf{j}=\mathbf{i}+\mathbf{1}}^{\mathbf{p}} \mathbf{A}_{\mathbf{j}}$ dan I adalah matriks identitas berukuran $\mathrm{n} \times \mathrm{n}$. Komponen vektor $\mathbf{y}_{\mathrm{t}}$ dikatakan terkointegrasi pada ordo ke-d jika semua komponen vektor $\mathbf{y}_{\mathbf{t}}$ stasioner sehingga terdapat vektor kointegrasi $\boldsymbol{\beta}$. Jika kombinasi linier $\boldsymbol{\beta}_{\mathbf{t}}$ stasioner pada ordo ke-d maka vektor $\mathbf{y}_{\mathbf{t}}$ terkointegrasi. Banyaknya vektor kointegrasi diperoleh dengan uji akar ciri (trace statistic) dan uji nilai eigen maksimum (maximum eigenvalue).

a. Uji Trace Statistic.

Uji trace statistic adalah uji nyata dari akar ciri pada matriks $\Pi$.

$\mathrm{H}_{0}$ : rank kointegrasi atau $\operatorname{rank}(\Pi) \leq \mathrm{k}$ (terdapat kointegrasi pada rank ke-

k)

$\mathrm{H}_{1}$ : rank kointegrasi atau $\operatorname{rank}(\boldsymbol{\Pi})>\mathrm{k}$ (tidak terdapat kointegrasi pada rank ke-k).

Statistik uji

$$
\lambda_{\text {trace }}(\mathrm{k})=-\mathrm{T} \sum_{\mathrm{i}=\mathrm{k}+1}^{\mathrm{n}} \ln \left(1-\hat{\lambda}_{\mathrm{i}}\right)
$$

dimana

$\hat{\lambda}_{\mathbf{i}}=$ akar ciri ke-i matriks $\Pi$

$\mathrm{n}$ = banyaknya peubah

$\mathrm{T}$ = banyaknya amatan.

Kriteria pengujian ada dua kemungkinan yaitu tolak $\mathrm{H}_{0}$ jika $\lambda_{\text {trace }}(\mathrm{k})<$ nilai kritis ( $\alpha=5 \%$ ), artinya tidak terdapat kointegrasi pada rank ke-k pada taraf nyata $(\alpha)$ sebesar $5 \%$. Dengan demikian model yang disarankan yaitu model VAR untuk data pemedaan. Sebaliknya, tidak tolak $\mathrm{H}_{0}$ jika $\lambda_{\text {trace }}(\mathrm{k})>$ nilai kritis $(\alpha=5 \%)$, artinya terdapat kointegrasi pada rank ke-k pada taraf nyata $(\alpha)$ sebesar $5 \%$. Dengan demikian model yang disarankan yaitu model VECM pada lag ke-p dan kointegrasi ke-k.

b. Uji Maximum Eigenvalue.

Uji maximum eigenvalue adalah uji nyata dari nilai eigen maksimum pada matriks $\Pi$.

Hipotesis yang akan diuji

$\mathrm{H}_{0}$ : rank kointegrasi atau $\operatorname{rank}(\Pi)=\mathrm{k}$ (terdapat kointegrasi pada rank ke- 
$\mathrm{H}_{1}$ : rank kointegrasi atau $\operatorname{rank}(\boldsymbol{\Pi})=\mathrm{k}+1$ (tidak terdapat kointegrasi pada rank ke-k).

Kriteria pengujian ada dua kemungkinan yaitu tolak $\mathrm{H}_{0}$ jika $\lambda_{\max }(\mathrm{k}, \mathrm{k}+1)<$ nilai kritis $(\alpha=5 \%)$, artinya tidak terdapat kointegrasi pada rank ke-k pada taraf nyata $(\alpha)$ sebesar $5 \%$. Dengan demikian model yang disarankan yaitu model VAR untuk data pembedaan. Sedangkan, tidak tolak $\mathrm{H}_{0}$ jika $\mathrm{H}_{0}$ jika $\lambda_{\max }(\mathrm{k}, \mathrm{k}+1)>$ nilai kritis $(\alpha=5 \%)$, artinya terdapat kointegrasi pada rank ke$\mathrm{k}$ pada taraf nyata $(\alpha)$ sebesar $5 \%$. Dengan demikian model yang disarankan yaitu model VECM pada lag ke-p dan kointegrasi ke-k.

7. Melakukan pendugaan parameter Model VECM dengan menggunakan data latih bulan Januari 2012 sampai Maret 2018.

8. Melakukan analisis pengaruh antar peubah dengan menggunakan komponen analisis FEVD dan komponen analisis IRF.

9. Melakukan pengujian kelayakan model dengan memeriksa korelasi diri antar sisaan menggunakan uji Portmanteau Ljung-Box. Analisis korelasi diri antar sisaan digunakan untuk memastikan kelayakan sebuah model yang telah dibangun.

Hipotesis yang akan diuji

$\mathrm{H}_{0}: \mathrm{r}_{1}=\mathrm{r}_{2}=\cdots=\mathrm{r}_{\mathrm{k}}$ (tidak ada korelasi diri dalam sisaan)

$\mathrm{H}_{1}$ : minimal ada sepasang $\mathrm{r}_{\mathrm{i}} \neq \mathrm{r}_{\mathrm{j}}$ untuk $\mathrm{i} \neq \mathrm{j}$ (terdapat korelasi diri antar sisaan).

Statistik uji

$$
\widetilde{\mathrm{Q}}_{\mathrm{LB}}(\mathrm{r})=\mathrm{n}(\mathrm{n}+2) \sum_{\mathrm{k}=1}^{\mathrm{m}} \frac{\mathrm{r}_{\mathrm{k}}^{2}}{\mathrm{n}-\mathrm{k}}
$$

(Ljung \& Box, 1978),

dimana

$\mathrm{n}=$ banyaknya peubah tak bebas dalam VAR

$\mathrm{r}_{\mathrm{k}}^{2}=$ koefisien korelasi diri antar sisaan sampai lag ke-k

$\mathrm{m}=$ jumlah lag maksimum.

Statistik $\widetilde{Q}_{\mathrm{LB}}$ mengikuti sebaran Chi-Square dengan derajat bebas $\mathrm{n}^{2}(\mathrm{k}-\mathrm{p})$, dimana $\mathrm{p}$ adalah ordo VAR. Kriteria pengujian, tidak tolak $\mathrm{H}_{0}$ jika nilai- $\mathrm{p}>$ taraf nyata $(\alpha=$ $5 \%)$. Artinya tidak ada korelasi diri dalam sisaan sampai lag ke-k pada taraf nyata (a) sebesar $5 \%$ atau model dikatakan layak.

10. Melakukan peramalan data uji bulan April 2018 sampai Juli 2018, berdasarkan model VECM dari data latih bulan Januari 2012 sampai Maret 2018

11. Menghitung evaluasi peramalan dengan menggunakan Mean Absolute Percentage Error (MAPE). Nilai MAPE pada evaluasi peramalan digunakan untuk mengukur kesesuaian antara data aktual dan data hasil peramalan. Semakin kecil nilai MAPE akan menghasilkan hasil ramalan yang akurat. Nilai MAPE dapat dihitung dengan rumus sebagai berikut: (Montgomery et al., 2008)

$$
\text { MAPE }=\frac{\sum_{\mathrm{t}=1}^{\mathrm{n}}\left|\frac{\widehat{Y}_{\mathrm{t}}-\mathrm{Y}_{\mathrm{t}}}{\mathrm{Y}_{\mathrm{t}}}\right|}{\mathrm{n}} \times 100 \%
$$


dimana

$\widehat{Y}_{t}=$ data data hasil peramalan pada periode ke-t

$Y_{t}=$ data aktual pada periode ke-t untuk $t=1,2, \ldots, n$

$\mathrm{n}$ = banyaknya ukuran sampel.

\section{Hasil dan Pembahasan}

\subsection{Eksplorasi Data}

Harga cabai merah di DKI Jakarta dan periode Januari 2012 sampai Juli 2018 berfluktuasi. Pola datanya cenderung tidak memiliki tren dan musiman dalam jangka panjang (Gambar 1). Rataan harga cabai merah di DKI Jakarta terlihat konstan (stasioner) dengan kisaran harga sebesar Rp34 935/kg. Sebaliknya, ragam data terlihat tidak stabil (tidak stasioner) dengan koefisien keragaman sekitar 37.00 persen. Angka koefisien keragaman ini di atas koefisien keragaman dari target Rencana Pembangunan Jangka Menengah Nasional (RPJMN) Kementerian Perdagangan (Kemendag) periode 2015 sampai 2019. Kemendag menetapkan stabilitas harga akan tercapai pada koefisien keragaman kurang dari 9 persen (Kemendag, 2016).

Harga cabai merah di daerah pemasok juga berfluktuasi dan memiliki pola yang hampir mirip dengan data harga cabai merah di DKI Jakarta. Rataan harga cabai merah di DKI lebih tinggi dibandingkan dengan rataan harga cabai merah di Jawa Timur (Rp22 989/kg) dan Banten (Rp29 909/kg) (Gambar 1). Namun, rataannya masih lebih rendah dibandingkan dengan rataan harga cabai merah di Jawa Barat yang berkisar Rp37 818/kg. Koefisien keragaman harga cabai merah di DKI Jakarta lebih stabil dibandingkan dengan koefisien keragaman harga cabai merah di Jawa Timur (45.02 persen) dan Banten (40.81 persen). Sebaliknya, koefisien keragamannya kurang stabil dibandingkan dengan koefisien keragaman harga cabai merah di Jawa Barat sekitar 34.52 persen.

Puncak tertinggi harga cabai merah di DKI Jakarta dan pemasoknya terjadi antara bulan November 2014 dan Desember 2014 (Gambar 1). Harga cabai merah di DKI Jakarta mencapai puncaknya sebesar Rp 82819/kg pada Desember 2014. Kejadian serupa terjadi pada harga cabai merah di Jawa Timur (Rp 64657/kg) dan Banten (Rp $84024 / \mathrm{kg}$ ). Sementara itu, harga cabai merah di Jawa Barat mencapai puncaknya sebesar Rp 73818/kg terjadi pada 1 bulan sebelumnya.

\subsection{Uji Kestasioneran Data}

Kestasioneran data berdasarkan grafik menghasilkan keputusan yang besifat sementara dan subjektif. Oleh karena itu, dibutuhkan uji formal kestasioneran data terhadap rataan dan ragam. Uji kestasioneran data dalam rataan dilakukan dengan uji akar unit ADF sedangkan uji kestasioneran data dalam ragam dilakukan dengan uji Barlett. 


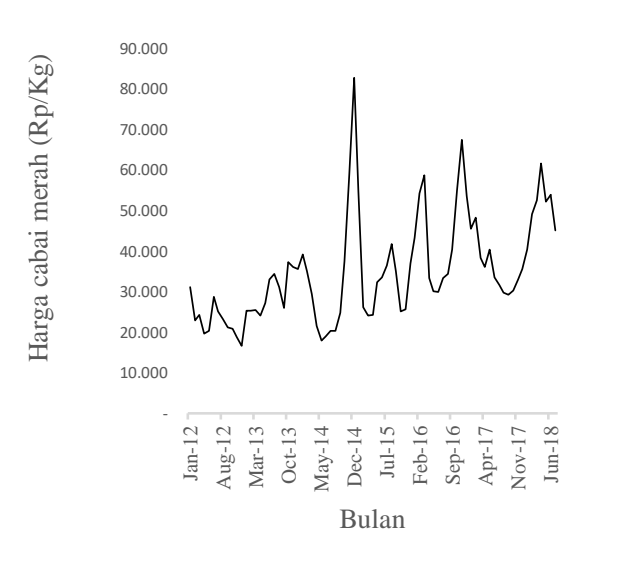

(a)

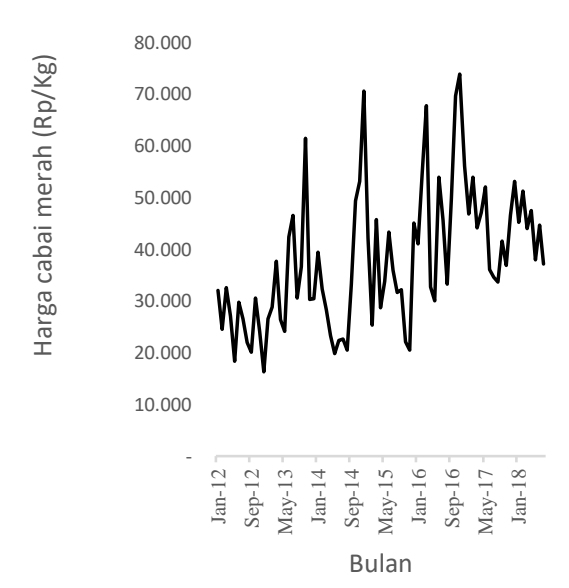

(c)

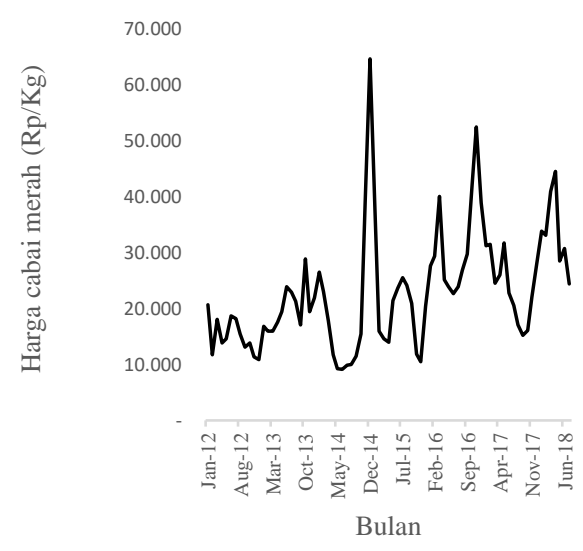

(b)

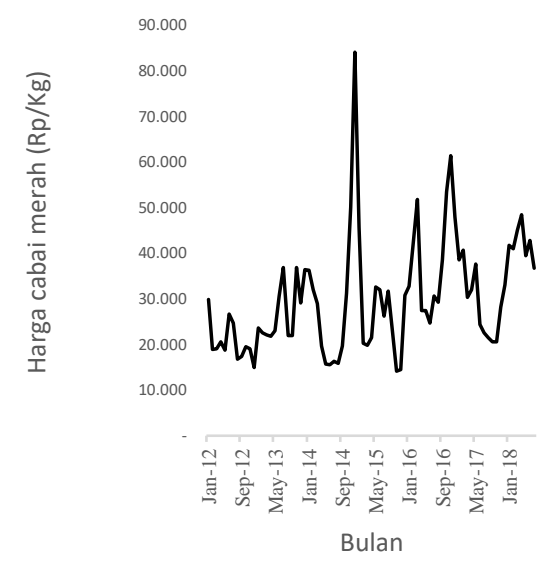

(d)

Gambar 1: Plot data harga cabai merah DKI Jakarta (a) dan harga cabai merah daerah pemasok DKI Jakarta : (b) Jawa Timur, (c) Jawa Barat dan (d) Banten periode Januari 2012 - Juli 2018.

Dalam rataan, hanya peubah pengeluaran rata-rata perkapita sebulan cabai merah DKI Jakarta tidak stasioner pada data level dengan taraf nyata $(\alpha)=0.05$ (Tabel 2). Sementara itu, dalam ragam, terdapat peubah harga cabai merah DKI Jakarta, harga cabai merah Jawa Timur, harga cabai merah Jawa Barat, harga cabai merah Banten, pengeluaran rata-rata perkapita sebulan cabai merah DKI Jakarta dan produksi cabai merah Banten yang tidak stasioner (tidak homogen) pada level dengan taraf nyata $(\alpha)$ $=0.05$. Penanganan peubah yang tidak stasioner dalam ragam dilakukan dengan transformasi logaritma natural. Sementara itu, penanganan peubah yang tidak stasioner dalam rataan dilakukan dengan pembedaan ordo ke-1. 
Tabel 2: Ringkasan uji kestasioneran data dalam rataan dan ragam.

\begin{tabular}{|c|c|c|c|c|c|c|}
\hline \multirow{2}{*}{$\begin{array}{l}\text { Nama } \\
\text { Peubah }\end{array}$} & \multicolumn{3}{|c|}{ Uji akar unit ADF } & \multicolumn{3}{|c|}{ Uji Bartlett } \\
\hline & thitung & Nilai $p$ & $\begin{array}{l}\text { Rataan } \\
\text { Stasioner }\end{array}$ & $X^{2}$ terkoreksi & Nilai $p$ & $\begin{array}{l}\text { Ragam } \\
\text { Stasioner }\end{array}$ \\
\hline $\mathrm{Y}$ & -4.58 & 0.00 & $\mathrm{Ya}$ & 38.48 & 0.00 & Tidak \\
\hline$X_{1}$ & -4.61 & 0.00 & Ya & 37.90 & 0.00 & Tidak \\
\hline$X_{2}$ & -4.54 & 0.00 & $\mathrm{Ya}$ & 21.24 & 0.00 & Tidak \\
\hline$X_{3}$ & -4.64 & 0.00 & $\mathrm{Ya}$ & 37.51 & 0.00 & Tidak \\
\hline$X_{4}$ & -1.65 & 0.77 & Tidak & 94.37 & 0.00 & Tidak \\
\hline$X_{5}$ & -4.92 & 0.00 & $\mathrm{Ya}$ & 8.10 & 0.23 & $\mathrm{Ya}$ \\
\hline$X_{6}$ & -4.39 & 0.00 & $\mathrm{Ya}$ & 9.54 & 0.15 & $\mathrm{Ya}$ \\
\hline$X_{7}$ & -4.93 & 0.00 & $\mathrm{Ya}$ & 70.87 & 0.00 & Tidak \\
\hline
\end{tabular}

\subsection{Pemilihan Kriteria Panjang Lag (p) Optimal}

Pemilihan kriteria panjang lag (p) optimal pada model harga cabai merah DKI Jakarta menggunakan data latih periode Januari 2012 sampai maret 2018. Lag optimal digunakan untuk melihat seberapa panjang periode yang masih berpengaruh nyata di antara peubah. Berdasarkan pelbagai kriteria panjang lag optimal diperoleh disajikan sebagai berikut pada Tabel 3 .

Tabel 3: Ringkasan pemilihan kriteria panjang lag optimal.

\begin{tabular}{ccccc}
\hline Lag & FPE & AIC & SIC & HQC \\
\hline 0 & $1.09 \mathrm{e}+10$ & 45.82 & 46.08 & 45.92 \\
1 & $4.52 \mathrm{e}+08^{\star}$ & 42.62 & $44.95^{\star}$ & $43.54^{\star}$ \\
2 & $7.48 \mathrm{e}+08$ & 43.05 & 47.46 & 44.80 \\
3 & $1.45 \mathrm{e}+09$ & 43.52 & 50.00 & 46.09 \\
4 & $1.06 \mathrm{e}+08$ & 42.80 & 51.35 & 46.19 \\
5 & $8.84 \mathrm{e}+08$ & 41.86 & 52.48 & 46.08 \\
6 & $1.08 \mathrm{e}+09$ & $40.66^{*}$ & 53.36 & 45.70 \\
\hline
\end{tabular}

Nilai kriteria FPE, SIC dan HQC minimum pada lag ke-1 sedangkan nilai kriteria AIC minimum pada lag ke-6. Dengan demikian, panjang lag optimal untuk model VAR yang disarankan yaitu lag ke-1 berbentuk VECM(1) dan lag ke-6 berbentuk VECM(6). Hal ini berarti bahwa lamanya pengaruh setiap peubah terhadap peubah lainnya pada model VECM harga cabai merah DKI Jakarta adalah 1 bulan dan 6 bulan.

\subsection{Pengujian Stabilitas Model VAR}

Pengujian stabilitas model VAR digunakan untuk memeriksa korelasi diri (autocorrelation) dan heteroskedastisitas di dalam penggunaaan model VAR (Enders, 2004). Semua nilai akar pada persamaan polinomial berada pada unit circle dan nilai modulus yang dihasilkan pada model VAR pada lag ke-1 bernilai kurang dari 1 . Sementara itu, hasil pengujian stabilitas VAR pada lag ke-6 menunjukkan bahwa ada 
7 nilai akar pada persamaan polinomial bernilai lebih atau sama dengan dari 1. Dengan demikian, model VAR yang digunakan sudah dalam kondisi stabil dengan lag ke-1 sebagai lag optimalnya.

\subsection{Pengujian Kausalitas Granger}

Pengujian Kausalitas Granger (Granger Causality) digunakan untuk mengetahui hubungan sebab akibat yang terjadi di antara peubah dalam model VAR harga cabai merah DKI Jakarta. Hasil uji Kausalitas Granger disajikan pada (lampiran 5). Kausalitas Granger terjadi ketika tolak $\mathrm{H}_{0}$ yaitu nilai $\mathrm{p}$ kurang dari taraf nyata $(\alpha)=5 \%$. Hubungan kausalitas Granger (

Gambar 2) menunjukkan bahwa terdapat keterkaitan kausalitas 1 arah antara harga cabai merah DKI Jakarta dan Jawa Barat terhadap harga cabai merah di Jawa Timur. Sementara itu, keterkaitan kausalitas 1 arah juga terjadi antara produksi cabai merah di Jawa Barat terhadap pengeluaran rata-rata perkapita sebulan cabai merah DKI Jakarta dan produksi cabai merah Jawa Timur.

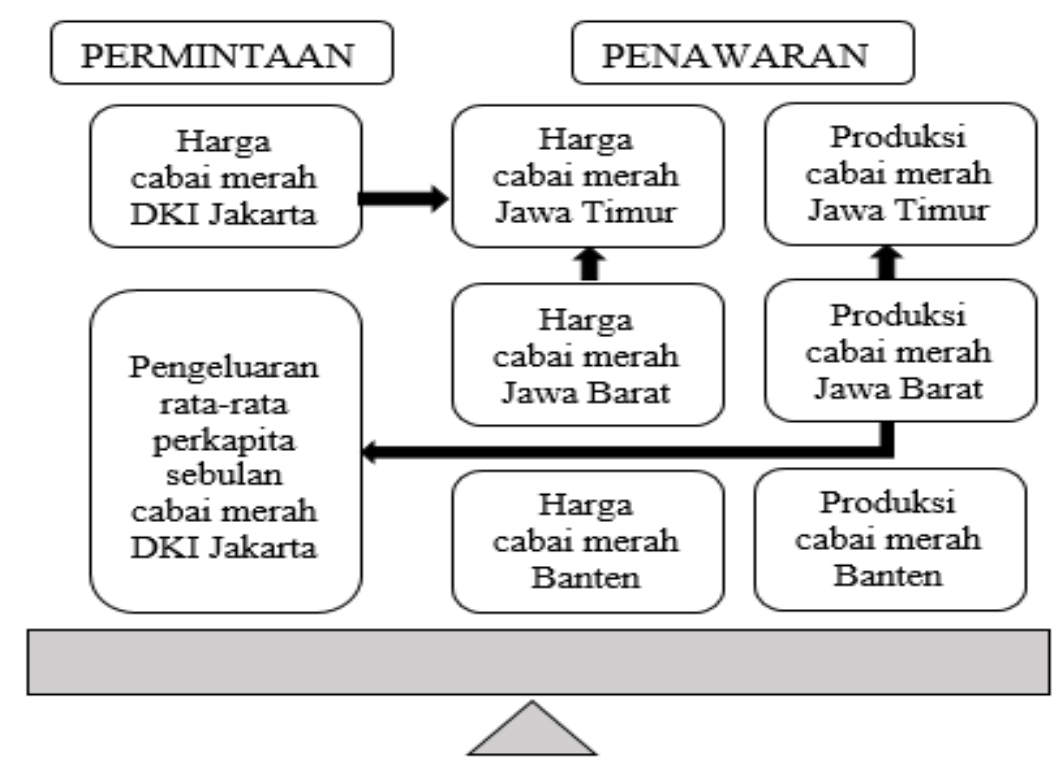

Keterangan: $\rightarrow$ terdapat hubungan kausalitas 1 arah

Gambar 2: Diagram hubungan uji kausalitas Granger.

\subsection{Pengujian Kointegrasi Johansen}

Pengujian kointegrasi digunakan untuk mengetahui kesamaan pola pergerakan dan stabilitas hubungan di antara peubah tak bebas di dalam mencapai keseimbangan jangka panjang. Hasil pengujian sampai baris ke-8 menunjukkan nilai teras (4.38) lebih besar daripada nilai kritis (3.84) dan dengan nilai $p(=0.04)$ lebih kecil daripada taraf nyata $(\alpha)=5 \%$ sehingga $\mathrm{H}_{0}$ tidak ditolak.

Hasil pengujian kointegrasi ini mengindikasikan adanya kointegrasi sampai rank ke-7. Hal ini dapat menjelaskan bahwa di antara peubah diantara peubah harga cabai 
merah DKI Jakarta, harga cabai merah Jawa Timur, harga cabai merah Jawa Barat, harga cabai merah Banten, pengeluaran rata-rata perkapita sebulan cabai merah DKI Jakarta, produksi cabai merah Jawa Timur, produksi cabai merah Jawa Barat dan produksi cabai merah Banten mempunyai kesamaan pola pergerakan dan stabilitas hubungan dalam keseimbangan jangka panjang. Dalam setiap periode jangka pendek, semua peubah saling menyesuaikan untuk mencapai keseimbangan jangka panjang.

\subsection{Pendugaan Parameter Model VECM(1) Harga Cabai Merah DKI Jakarta}

Melalui pembuktikan pengujian stabilitas model VAR(1) dan kointegrasi Johansen, model yang terbentuk adalah VECM(1). Persamaan linier VECM(1) harga cabai merah DKI Jakarta dapat dituliskan sebagai berikut:

$$
\begin{gathered}
\Delta \mathrm{Y}_{1}=-0.28 \mathrm{Y}_{1(\mathrm{t}-1)}+0.51 \mathrm{X}_{1(\mathrm{t}-1)}-2.12 \mathrm{X}_{2(\mathrm{t}-1)}+0.40 \mathrm{X}_{3(\mathrm{t}-1)}+0.32 \mathrm{X}_{4(\mathrm{t}-1)}-(1.64 \mathrm{x} \\
\left.\left.10^{-6}\right) \mathrm{X}_{5(\mathrm{t}-1)}+\left(1.06 \times 10^{-6}\right) \mathrm{X}_{6(\mathrm{t}-1)}+0.03 \mathrm{X}_{7(\mathrm{t}-1)}-0.43\right)+0.32 \Delta \mathrm{Y}_{1(\mathrm{t}-1)}+ \\
0.11 \Delta \mathrm{X}_{1(\mathrm{t}-1)}-0.43 \Delta \mathrm{X}_{2(\mathrm{t}-1)+0.12 \Delta \mathrm{X}_{3(\mathrm{t}-1)}-0.45 \Delta \mathrm{X}_{4(\mathrm{t}-1)}-(7.96 \mathrm{x}} \\
\left.10^{7}\right) \Delta \mathrm{X}_{5(\mathrm{t}-1)}+\left(1.99 \times 10^{-7}\right) \Delta \mathrm{X}_{6(\mathrm{t}-1)}-0.12 \Delta \mathrm{X}_{7(\mathrm{t}-1)}+0.02 .
\end{gathered}
$$

\begin{tabular}{|c|c|c|c|c|c|}
\hline Peubah & Koefisien & thitung & Peubah & Koefisien & thitung \\
\hline Error & & & \multicolumn{3}{|c|}{ Cointegrating } \\
\hline Correction & & & \multicolumn{3}{|l|}{ Eq: } \\
\hline Coint Eq1 & -0.28 & $-3.37^{*}$ & \multirow{2}{*}{\multicolumn{3}{|c|}{ Jangka Panjang }} \\
\hline & Jangka Pendek & & & & \\
\hline$\Delta \mathrm{Y}_{1}(-1)$ & 0.32 & 1.11 & $\mathrm{Y}_{1}(-1)$ & 1.00 & \\
\hline$\Delta \mathrm{X}_{1}(-1)$ & 0.11 & 0.54 & $X_{1}(-1)$ & 0.51 & 1.57 \\
\hline$\Delta \mathrm{X}_{2}(-1)$ & -0.43 & $-3.23^{*}$ & $X_{2}(-1)$ & $-2,12$ & $-8.84^{*}$ \\
\hline$\Delta \mathrm{X}_{3}(-1)$ & 0.12 & 0.64 & $X_{3}(-1)$ & 0.40 & 1.04 \\
\hline$\Delta \mathrm{X}_{4}(-1)$ & -0.45 & -1.84 & $X_{4}(-1)$ & 0.32 & 1.64 \\
\hline$\Delta X_{5}(-1)$ & $-7.96 \times 10^{-7}$ & -0.92 & $X_{5}(-1)$ & $-1.64 \times 10^{-6}$ & 0.92 \\
\hline$\Delta \mathrm{X}_{6}(-1)$ & $1.99 \times 10^{-7}$ & 0.45 & $X_{6}(-1)$ & $1.06 \times 10^{-6}$ & 1.29 \\
\hline$\Delta \mathrm{X}_{7}(-1)$ & -0.12 & $-2.93^{*}$ & $X_{7}(-1)$ & 0.03 & 0.40 \\
\hline C & 0.02 & 0.76 & C & -0.43 & \\
\hline
\end{tabular}

Tabel 4: Ringkasan pendugaan parameter VECM(1).

Keterangan: *Nilai taraf nyata $5 \%=$ tabel $(1,96)$

Nilai Error Correction Term (ECT) pada VECM(1) harga cabai merah DKI Jakarta sebesar -0.28 (Tabel 4) menunjukkan bahwa terdapat besarnya kecepatan penyesuaian untuk mencapai keseimbangan dari jangka pendek ke jangka panjang apabila terjadi penyimpangan akan dikoreksi sebesar 0.28 persen. Ini artinya bahwa terdapat hubungan kointegrasi jangka panjang dalam menentukan harga cabai merah di DKI Jakarta.

Pada jangka panjang dan pendek, harga cabai merah di DKI Jakarta pada saat ini dipengaruhi oleh harga cabai merah di Jawa Barat pada 1 bulan sebelumnya pada taraf nyata $5 \%$. Sementara itu, pada jangka pendek saja, harga cabai merah di DKI 
Jakarta pada saat ini dipengaruhi oleh produksi cabai merah Banten pada 1 bulan sebelumnya pada taraf nyata $5 \%$.

\subsection{Analisis Forecast Error Decomposition Variance (FEDV)}

Pada analisis ini akan dilihat peranan FEVD pada sistem dinamis VECM(1) harga cabai merah DKI Jakarta dalam mengukur kontribusi setiap peubah pada jangka panjang sepanjang 12 periode. Hasil FEVD harga cabai merah di DKI Jakarta pada bulan ke-1 memperlihatkan bahwa perilaku perubahan harga cabai merah di DKI Jakarta dijelaskan oleh peubahnya sendiri sekitar 100 persen (Gambar 3). Bulan ke-2 kontribusi peubah harga cabai merah DKI Jakarta sendiri dalam menjelaskan perilaku perubahan harga cabai merah di DKI Jakarta menurun sekitar 91.07 persen hingga bulan ke-12 sekitar 68.11 persen. Pada bulan ke-2 peubah harga cabai merah di daerah pemasok telah dapat menjelaskan perilaku perubahan harga cabai merah di DKI Jakarta. Besaran kontribusi peubah harga cabai merah daerah pemasok di Jawa Timur (0.31 persen), Jawa Barat (1.06 persen) dan Banten (0.16 persen). Hingga bulan ke-12, besaran kontribusi peubah harga cabai merah daerah pemasok meningkat di Jawa Barat (12.61 persen) dan Banten (0.33 persen) sedangkan kontribusi peubah harga cabai merah daerah pemasok menurun di Jawa Timur sebesar 0.18 persen.

Perilaku harga cabai merah di DKI Jakarta mulai dapat dijelaskan oleh peubah pengeluaran rata-rata perkapita sebulan cabai merah di DKI Jakarta pada bulan ke-2 sekitar 2.22 persen dan mulai meningkat pada bulan berikutnya (Gambar 3). Hingga bulan ke-12, besaran kontribusi peubah pengeluaran rata-rata perkapita cabai merah di DKI Jakarta mencapai 6.42 persen.

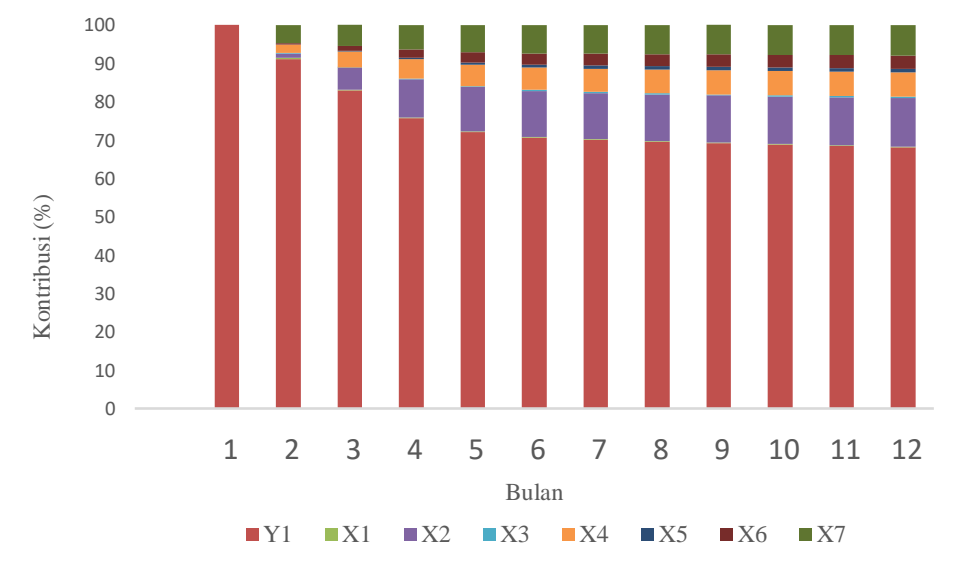

Gambar 3: Hasil FEDV model VECM(1) harga cabai merah DKI Jakarta.

Besaran kontribusi peubah produksi cabai merah daerah pemasok di Banten dan Jawa Barat dalam menjelaskan perilaku harga cabai merah di DKI Jakarta mulai ada pada periode ke-2, masing-masing sekitar 4.79 persen dan 0.38 persen (Gambar 3). Sementara itu, peubah produksi Jawa Timur belum berkontribusi dalam menjelaskan perilaku harga cabai merah di DKI Jakarta pada periode ini. Kontribusi produksi cabai merah daerah terus meningkat pada bulan berikutnya. Hingga bulan ke-12, besaran kontribusi peubah produksi cabai merah daerah pemasok dalam menjelaskan perilaku 
perubahan harga cabai merah DKI Jakarta, masing-masing di Jawa Timur (0.96 persen), Jawa Barat (3.44 persen) dan Banten (7.95 persen).

\subsection{Analisis Impulse Response Function (IRF)}

Analisis IRF dilakukan untuk mengetahui informasi respon pergerakan peubah harga cabai merah DKI Jakarta pada jangka pendek dan panjang kepada goncangan (shock) sebesar 1 SB peubahnya sendiri dan peubah lainnya. Sumbu datar adalah periode selama 12 bulan dan sumbu tegak adalah respon perubahan harga cabai merah di DKI Jakarta (dalam SB).

Respon pergerakan harga cabai merah DKI Jakarta pada shock peubahnya sendiri terlihat positif pada periode pertama (Gambar 4a). Pada Bulan ke-2 mulai terlihat respon harga cabai merah DKI Jakarta pada shock peubah harga cabai merah daerah pemasoknya. Bulan ke-3 merupakan periode puncak respon harga cabai merah DKI Jakarta pada shock peubahnya sendiri berkisar 0.24 SB. Selanjutnya, respon harga cabai merah DKI Jakarta berfluktuasi perlahan hingga mencapai hubungan jangka panjang (stabil) sejak bulan ke-7 berkisar $0.22 \mathrm{SB}$.

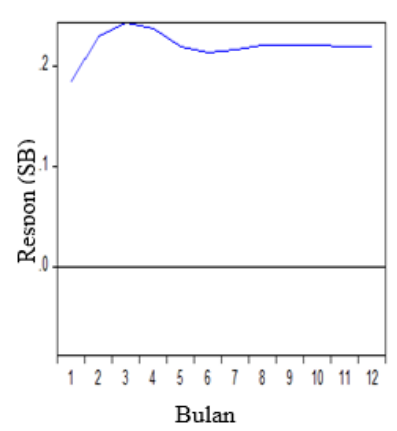

(a)

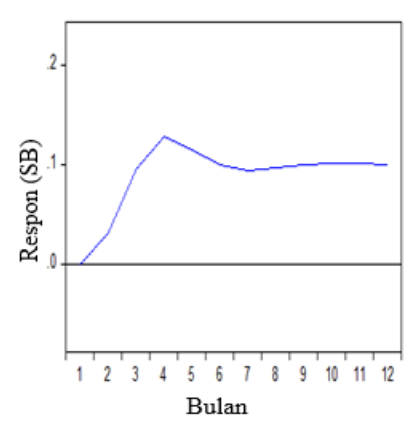

(b)

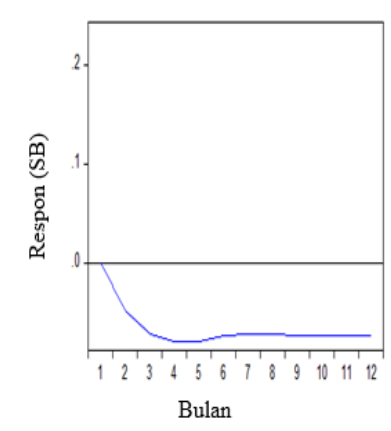

(c)

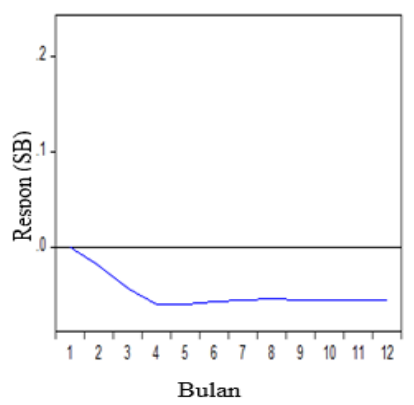

(d)

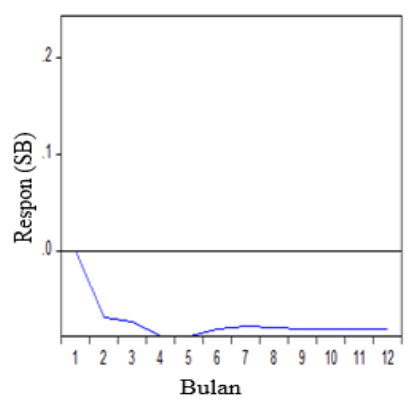

(e)

Gambar 4: Hasil IRF VECM(1) respon harga cabai merah DKI Jakarta pada shock (a) harga cabai merah DKI Jakarta, (b) harga cabai merah Jawa Barat, (c) pengeluaran rata-rata perkapita sebulan cabai merah DKI Jakarta, (d) produksi cabai merah Jawa Barat dan (e) produksi cabai merah Banten. 
Sementara itu, respon positif terjadi pada respon harga cabai merah DKI Jakarta pada shock harga cabai merah di Jawa barat (Gambar 4b). Puncak respon tertinggi terjadi pada bulan ke-4 berkisar $0.13 \mathrm{SB}$, kemudian stabil pada bulan ke-8 berkisar 0.10 SB.

Adanya shock pengeluaran rata-rata perkapita sebulan di DKI Jakarta direspon negatif oleh harga cabai merah di DKI Jakarta pada bulan ke-2 berkisar 0.05 SB (Gambar 4c). Respon harga cabai merah DKI Jakarta berfluktuasi menurun perlahan hingga mencapai lembah terendahnya pada bulan ke-4 berkisar 0.08 SB. Kestabilan respon harga cabai merah DKI Jakarta terjadi pada bulan ke-6 pada kisaran $0.07 \mathrm{SB}$.

Adanya shock produksi cabai merah daerah pemasok mulai direspon negatif oleh harga cabai merah di DKI Jakarta pada bulan ke-2 (Gambar 4). Respon negatif harga cabai merah DKI Jakarta pada shock produksi cabai merah daerah pemasok menurun dan terus berlanjut hingga pada bulan-bulan setelahnya. Adanya shock produksi cabai merah di Jawa Barat dan Banten direspon negatif harga cabai merah di DKI Jakarta mencapai lembah terendah pada bulan ke-5, masing-masing berkisar 0.06 SB dan 0.09 SB. Respon harga cabai merah DKI Jakarta pada shock produksi cabai merah di Banten langsung stabil sejak bulan berikutnya berkisar 0.08 SB. Sementara itu, respon harga cabai merah DKI Jakarta pada shock produksi cabai merah di Jawa Barat menjadi stabil pada bulan ke-7 berkisar 0.05 SB.

\subsection{Pengujian kelayakan model VECM(1) Harga Cabai Merah DKI Jakarta}

Pengujian kelayakan model dilakukan dengan cara memeriksa korelasi diri (Autocorrelation) antar sisaan peubah pada model VECM(1) harga cabai merah di DKI Jakarta. Hasil pengujian kelayakan VECM(1) menggunakan uji Portmenteau Ljung-

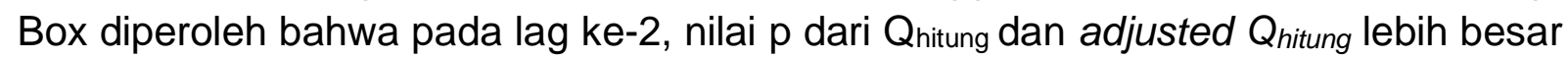
dari taraf nyata $(\alpha)=5 \%$ atau tidak tolak $\mathrm{H}_{0}$. Hingga pada lag ke-12 nilai $p$ dari $Q_{\text {hitung }}$ dan adjusted $Q_{\text {hitung }}$ lebih besar dibandingkan dengan taraf nyata $(\alpha)=5 \%$ sehingga (tidak tolak $\mathrm{H}_{0}$ ). Ini artinya bahwa tidak ada korelasi diri antar sisaan pada model VECM(1) cabai merah DKI Jakarta. Dengan demikian model tersebut dikatakan layak untuk digunakan.

\subsection{Evaluasi Peramalan model VECM(1) Harga Cabai Merah DKI Jakarta}

Evaluasi peramalan model VECM(1) harga cabai merah DKI Jakarta dilakukan dengan menghitung nilai MAPE. Nilai MAPE dihitung dengan mengukur kesesuaian antara data aktual harga cabai merah DKI Jakarta dan data peramalan harga cabai merah DKI Jakarta. Nilai MAPE yang dihasilkan dari VECM(1) harga cabai merah DKI Jakarta sebesar 29.97 pesen. Hal ini menunjukkan bahwa VECM(1) mempunyai kemampuan yang cukup baik untuk peramalan harga cabai merah DKI Jakarta.

\section{Simpulan}

Model VECM(1) menunjukkan hubungan keseimbangan jangka panjang (kointegrasi) antar peubah di dalam penentuan harga cabai merah di DKI Jakarta. Hasil FEVD pada model VECM(1) harga cabai merah DKI Jakarta menunjukkan bahwa kontribusi 
peubah harga cabai merah DKI Jakarta sendiri, harga cabai merah Jawa Barat, pengeluaran rata-rata perkapita sebulan cabai merah DKI Jakarta, produksi cabai merah Jawa Barat dan produksi cabai merah Banten sudah nyata dalam menjelaskan perilaku perubahan harga cabai merah di DKI Jakarta. Hasil analisis IRF pada model VECM(1) harga cabai merah DKI Jakarta menunjukkan adanya shock pada harga cabai merah DKI Jakarta sendiri dan harga cabai merah Jawa Barat 1 bulan sebelumnya dapat meningkatkan harga cabai merah di DKI Jakarta saat ini. Sebaliknya, adanya shock pengeluaran rata-rata perkapita sebulan cabai merah DKI Jakarta, produksi cabai merah Jawa Barat dan produksi cabai merah Banten 1 bulan sebelumnya dapat menurunkan harga cabai merah di DKI Jakarta saat ini.

\section{Daftar Pustaka}

Ajija, S.R., Sari, D.W., Setianto, R.H. and Primanti, M.R. (2011). Cara cerdas menguasai Eviews. Jakarta (ID): Salemba Empat.

[BPS] Badan Pusat Statistik. (2015). Distribusi perdagangan komoditas bawang merah Indonesia 2015. Jakarta (ID): Badan Pusat Statistik.

[BPS] Badan Pusat Statistik. (2019). Indeks harga konsumen dan inflasi DKI Jakarta 2018. Jakarta (ID): Badan Pusat Statistik.

Dickey, D.A., and Fuller, W.A. (1979). Distribution of the estimators for autoregressive time series with a unit root. Journal of the American statistical association, 74(366a):427-431.

Enders, W. (2004). Applied econometric time series, 2 nd. ed. New York (US): John Willey \& Sons, Inc.

Farid, M., and Subekti, N.A. (2012). Tinjauan terhadap produksi, konsumsi, distribusi dan dinamika harga cabe di Indonesia. Buletin Ilmiah Litbang Perdagangan, 6(2):211-234.

Gujarati, D. (2003). Basic econometrics, 4th ed. New York (US): McGraw Hill.

Hatidja, D. (2000). Pembandingan uji barlett, jacknife dan levene untuk pengujian kehomogenan ragam [tesis]. Bogor (ID): IPB University.

Johansen, S. (1991). Estimation and hypothesis testing of cointegration vectors in Gaussian vector autoregressive models. Econometrica: journal of the Econometric Society, 1551-1580.

Juanda, B., and Junaidi. (2012). Ekonometrika Deret Waktu: Teori dan Aplikasi. Bogor (ID): IPB Press.

[Kemendag] Kementerian Perdagangan RI. (2016). Peraturan Menteri Perdagangan Republik Indonesia Nomor 63 tahun 2016 tentang penetapan harga acuan pembelian di petani dan harga acuan penjualan di konsumen. Jakarta (ID): Kementerian Perdagangan RI. 
Ljung, G.M., and Box, G.E. (1978). On a measure of lack of fit in time series models. Biometrika, 65(2):297-303.

Montgomery, D., Jennings, C., and Kulahci, M. (2008). Introduction to time series analysis and forecasting. New Jersey (US): John Wiley \& Sons.

Nauly, D. (2017). Fluktuasi dan disparitas harga cabai di Indonesia. Jurnal Agrosains dan Teknologi, 1(1):57-70.

Prastowo, N.J., Yanuarti, T., and Depari, Y. (2008). Pengaruh distribusi dalam pembentukan harga komoditas dan implikasinya terhadap inflasi. The Effect of Distribution on Commodity Pricing and Its Implications for Inflation]. Working Paper, WP/07/2008. Jakarta: Bank Indonesia,.

[Pusdatin - Kementan], Pusat Data dan Sistem Informasi Pertanian. (2016). Outlook komoditas pertanian sub sektor hortikultura: cabai merah. Jakarta (ID): Pusdatin Kementerian Pertanian RI.

Rozfaulina. (2000). Analisis pendapatan usahatani dan saluran pemasaran cabai merah keriting. Kasus tiga desa di kecamatan sukaraja, kabupaten sukabumi, jawa barat. [skripsi]. Bogor (ID): IPB University.

Sari, R. (2013). Tingkat inflasi dan pembatasan kebijakan impor hortikultura. Info Singkat, 5:13-16.

Sims, C.A., Stock, J.H., and Watson, M.W. (1990). Inference in linear time series models with some unit roots. Econometrica, 58(1):113-144.

Sukmawati, D., Sulistyowati, L., Karmana, M.H., and Wikarta, E.K. (2017). Fluktuasi harga cabai merah keriting (Capsicum annum L) di sentra produksi dan pasar induk (tinjauan harga cabai merah keriting di Kecamatan Cikajang dan Pasar Induk Kramat Jati Jakarta). Mimbar Agribisnis: Jurnal Pemikiran Masyarakat Ilmiah Berwawasan Agribisnis, 1(2):165-172.

Syah, M.J.A., Sayekti, A.L., Marendra K., A., and Hilman, Y. (2015). Dinamika produksi dan volatilitas harga cabai: antisipasi strategi dan kebijakan pengembangan. Pengembangan Inovasi Pertanian, 8(1):33-42.

Wulandari, H., Kurnia, A., Sumantri, B., Kusumaningrum, D., Waryanto, B. 2017. Penerapan analisis regresi spline untuk menduga harga cabai di Jakarta. Indonesian Journal of Statistics and Its Applications, 1(1):1-12. 